\title{
沖積地盤におけるシールド掘進に伴う地盤変状と その予測解析について \\ BEHAVIOR OF GROUND DISPLACEMENT DUE TO SHIELD THRUSTING IN ALLUVIAL SUBSOILS AND ITS PREDICTION ANALYSIS
}

\author{
山田孝治*.吉田 保**. 間片博之*** ・橋本定雄**** \\ By Koji YAMADA, Tamotsu YOSHIDA, Hiroyuki MAGATA \\ and Sadao HASHIMOTO
}

\begin{abstract}
Characteristics and mechanism of ground displacement during ; shield thrusting in soft ground were discussed. It is pointed out that the shield machine, auxiliary construction methods, backfill grout and the quality of operation control are the main influencing factors and should duly be taken into account for the prediction of ground displacement. The numerical calculation by two dimensional elastic finite element method with some modeling techniques was confirmed to provide an excellent method to predict the 3-dimensional ground displacement behavior under shield thrusting.
\end{abstract}

\section{1. まえがき}

近年，都市におけるシールドトンネルは，各種の重要 構造物に近接して施工されることが多く，シールド掘進 に際しては，近接構造物に変状を与えないことが厳しく 要求されている. そのために，シールド掘進に伴う地盤 変状自体を小さくすること，または地盤変状の影響を遮 断することを目的として，地盤を強化するための薬液注 大工法，地中連続壁工法などが，防護工として頻繁に採 用されてきた1) 7). そして，このような対策を行った箇 所では必ず詳細な動態計測を実施している.

これらの箘所では当然, シールド機種の選定, 掘進管 理，裏込め注入管理などに細心の注意が払われており， その結果ほとんどの工事で, 地盤変状の計測值が管理值 を大きく下回っている. このことから, 動態計測管理を 行いながら施工を慎重に行えば，防護工が不要か，また は必要な場合でも，その規模を縮少できたのではないか

* 正会員 工修 日本工営株式会社第三土木技術部次長 （干102/千代田区鶄町 5-4）

** 正会員 日本工営株式会社第三土木技術部 (同 上)

*** 正会員 工博 明星大学教授 理工学部 (宁191/日野市程久保 337)

**** 正会員 工博 東京都下水道局局長 （干100/千代田区大手町 2-6-2)
との疑念が拭い去れない.すなわち，これまでの行き方 では，動態計測を行って慎重に施工したものの，積極的 にシールド工事を経済的に行ったとはいいがたい. この 感想はおそらく，近接シールド施工を行った技術者のす べてに共通したものであろう.

著者らは，ある上下隣接シールド工事において，動態 計測による入念な施工管理を行い，特に防護工を施すこ となく, 無事シールド掘進を完了させた経験をもってい る . これは, 著者ら ${ }^{9}$ が以前行った篠崎幹線シールド 工事における地盤変状の実態調查の結果を踏まえて, 地 盤変状の予測解析を行い, 当該地の変状は許容值以下で あると判断できたこと, および施工中の動態計測によっ て，その予測が確認されたことによるものである.

このように，動態計測結果を積極的に施工を生かすた めには,

(1) シールド掘進に伴う地盤変状のメカニズムの把握

(2) 必要とする精度で, 問題となる地盤変状の予測解 析が行えること

の 2 点が必要である.

これまで，(1) と (2)に関する研究はそれぞれ数多く行 われてきた.

(1)について主なものを述べると, 森 ${ }^{10)}$ は, シールド掘 進に伴う地盤変状は，シールド掘進による応力解放のた めの地盤変形のほかに, 地山がせん断変形を受け土の構 
造が乱されることによる圧密沈下が大きいウェイトを占 めることを指摘した． 藤原ら ${ }^{11) 131}$ は，土圧式シールド で粘性土地盤，砂質土地盤を掘進した場合に詳細な現場 計測を行い，地盤変状のメカニズムを検討している．彼 らはまた, シールド機周辺の地盤の動きと, 地山の乱れ なども詳細に報告している. 古山ら ${ }^{14), 15)}$ は粘性土地盤 中に，ブラインド式，土圧式，および泥土加圧式シール ドで掘進した場合の地盤の変状を詳細に計測し, 各方式 がそれぞれ特徵ある地盤変状を示したことを報告してい る. 森 ${ }^{16)}$, 小林 ${ }^{17)}$ は模型実験により, 切羽の安定を検討 乙, 切羽の取り込み量と地山の動きに密接な関係がある ことを指摘している. 著者らも過去 7 8 年間に, 東京 の沖積地盤における シールド掘進に伴う地盤変状を 20 数例計測し，その一部を報告してきた ${ }^{7), 8), 18), 19)}$.

以上のほかにも，現場計測は数多く行われてきてお り，それぞれ，シールド掘進に伴う地盤変状の実態，変 状の原因などの分析が行われている. しかし，これらの 資料を網羅するようなかたちで, 地盤変状とその原因を 考察したもの，さらに次に迹べる地盤変状の予測解析と 関連づううとした論文は, 著者らの知る限り見当たら ない.

次に前記の(2)について, これまでの動向を述べると， 最近の近接施工において要求される予測解析では, トン ネル径, 土被り厚さなどの幾何学的な寸法形状のほか に, 複雑な土質条件, シールド機種, 掘進管理の内容, 裹込め注入の分量, 防護工の効果等を組み込んで評価で きるものでなければならない.

このような観点から地盤変状の算定式を概観すると, Peck の式 ${ }^{20)}$, Jeffery の式 ${ }^{21)}$ 等の慣用式は概略の目安を 与えるのみで, 多くの要因の影響を表わし得ない。

伊藤, 久武 ${ }^{22) ~ 24)}$ は 境界要素法を用いて, 地盤を粘弾 性体として取り扱い, テールボイド量, 圧気圧, シール ド切羽位置とその進行速度など，かなり施工条件を考慮 できる計算方法を提案している. しかし，この方法にお いては, シールド切羽推力の大小, 薬液注大による局部 的な地盤改良の効果, トンネルセグメントの剛性をどの ように評価するかなどの諸点が，なお不明のまま残され ている.

著者ら ${ }^{25), 33)}$ は有限要素法を用いて,テールボイドの大 きさ, 裹込め注大の分量, および, セグメントの剛性を評 価して, 地盤変状予測を行った. これは本論文の一部を なすものである. その後, 古山ら ${ }^{14)}$ は同様のことを解放 率 0 を導入して解析することを試みている. また，寺田 $ら^{26)}$ は強制変位法と名付けた手法によって, テールボイ ドの大きさを評価している. しかし，この手法ではセグ メントの剛性を沈下量算定の中に大れることをしていな い, 以上のほかにも, 有限要素法による沈下解析例は多
いが，2,3 の例外を除けば，テールボイド量，セグメン 卜剛性の取り扱いが不明, または, 素掘り掘削断面のも のがほとんどである.

以上は，横断面方向の地盤変状解析であるが，縦断面 方向の解析を行った報告は案外少なく，木村27)，Gha-

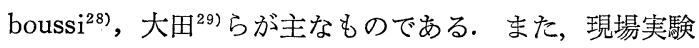
值との照合の事例が少ない.

このように, 予測解析手法についてはかなり研究が進 んでいるものの, 地盤条件, 施工条件等が複雑なため に，すべてを適切に考慮に入れた計算法は確立されてい ないのが現状である.

\section{2. シールド掘進に伴う地盤変状の実態}

地盤変状の特徵は, 変位の分布形状, ある一点の变位 の経時変化, 地盤の乱れなどに現われる. 以下にこれら の事項について, 今までの研究で判明したことを述べ る.

\section{（1）地盤変状の分布}

まず, シールド掘進に伴って, 地盤はどのように挙動 するかを, 篠崎幹線の測定例に基づいて述べる.

図一1 4 は, $w_{L}=45 \sim 50 \%, w_{P}=30 \sim 35 \%, w=40$ $\sim 70 \%, q_{u}=5 \sim 7 \mathrm{tf} / \mathrm{m}^{2}$ 程度の超鋭敏粘土からなる沖積 粘性土地盤を, 図一5 8 は $N$ 值=5 10 の沖積砂地 盤をいずれも，土圧式シールドで掘進した場合の典型的 な事例 ${ }^{18)}$ である. いずれの場合も地表面で沈下のみが生 ビたケースである.

地盤変状の特徵はこれらの図が示すように, シールド 機本体を中心に三次元的に広がり，しかもその分布がシ ールド機の進行とともに移動することである.

まず粘性土地盤について述べる. 図一1 はシールド機 が破線の位置にあるときの地表面の沈下コンターの一例 である. シールド機の進行とともに，このコンターも移 動する. 図一2 は地中における鉛直, 水平変位の横断方 向の分布を示す. 鉛直変位のコンターはシールド切羽に おいてその分布幅は狭いが, シールド機通過後, 約 6 か 月経った時点（最終状態とよぶ）ではその幅が広がり変

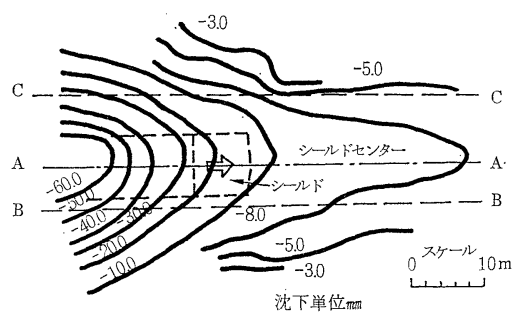

図一1地表面沈下コンター

（篠崎幹線 $4-2$ 地点 粘性土地盤） 


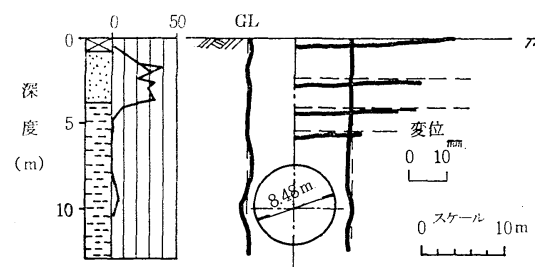

(a)鉛值・水平変位（切羽比找ける分布）

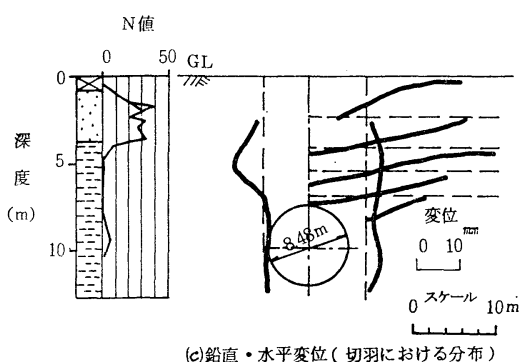

(c)鉛值・水平変位 (切羽における分布)

図一2 地中鉛直・水平変位の横断分布図（篠㥓幹線 4-2 地点 粘性土地盤）

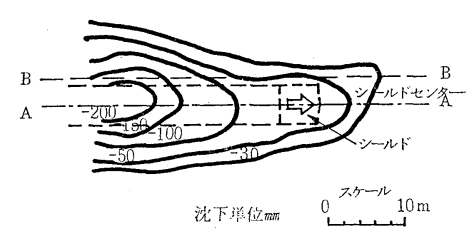

図一5 地表面沈下コンター

（篠崎幹線 6-4 地点 砂地盤）
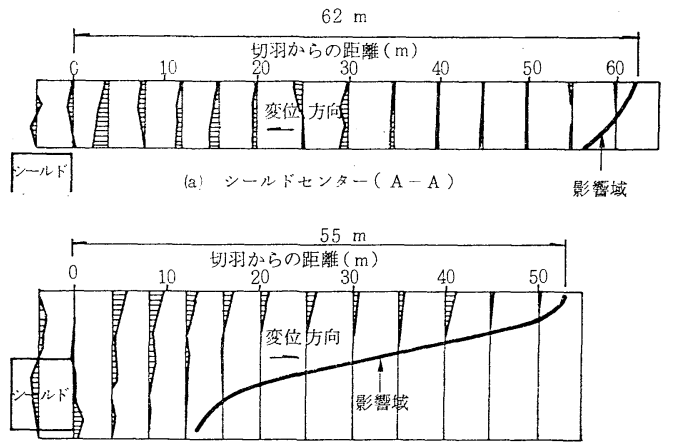

(b) シールド側端から $1.5 \mathrm{~m}(\mathrm{~B}-\mathrm{B})$

$43 \mathrm{~m}$

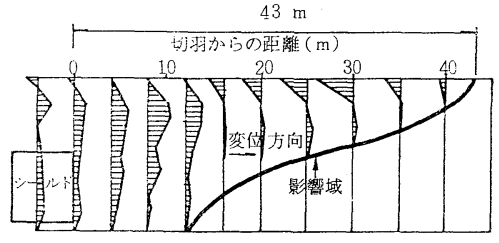

(c) シールド側端から $4.0 \mathrm{~m}(\mathrm{C}-\mathrm{C})$

図一3 地中水平変位の縦断分布

（篠崎幹線 4-2 地点 粘性土地盤）

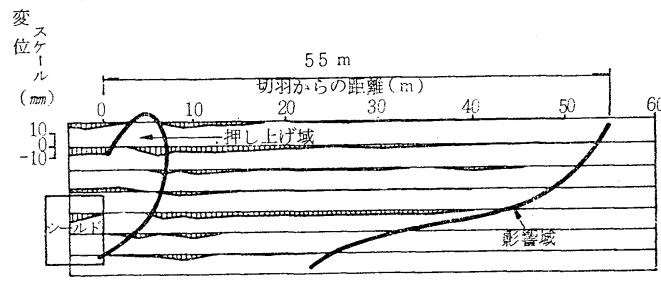

図-4 地中鉛直変位の縦断分布 (B-B)

（篠崎幹線 4-2 地点 粘性土地盤）

位範囲はほぼ $45^{\circ}$ の広がりをもっている．最終状態の， 沈下コンターは鉛直に近く, 地表と地中の変位にはほと んど差はない，水平変位はシールド機通過によって，シ

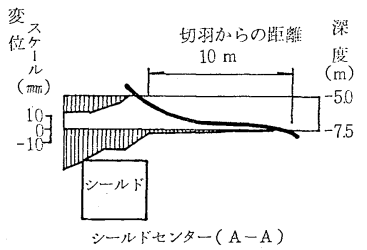

図一7地中鉛直変位の縦断分布

（篠崎幹線 6-4 地点 砂地盤）

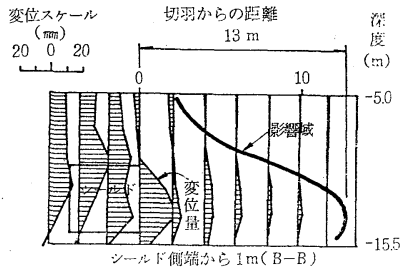

図一8地中水平変位の縦断分布

（篠崎幹線 6-4 地点 砂地盤）

ールド機の外方に動く傾向がみられる. 図一3 はシール ドセンターライン (A-A) と側方の地盤中 (B-B, C-C) の 3 つの縦断面に打ける, シールド切羽前方の地盤中の 水平変位である. 図一4 は (B-B) における鉛直変位分 布を示す．シールド側方の土は進行方向に，また，切羽 正面の土はシールド側に動いている.これはそれぞれシ ールド外壁の摩擦のためと，切羽正面で土塊を取り达ん でいるためである.

以上の事例を含め，著者らの経験を総合すると，図一 9 に示すように地盤が動いているものと結論できる。 そ の特徴を要約すると次のようである.

(1) シールド切羽正面に土の取り込み域が発生し，こ の部分の土はシールド方向に動いている（シールド 掘進の操作によってはこの動きが生じないこともあ り得る). 
(2) 取り込み域の外の地盤はシールド本体外周の摩擦 によって，シールド進行方向に押される.

(3) 切羽前面の地盤は上の例では沈下している(シー ルド掘進の操作によっては隆起する場合がある).

(4) テールより背後の地盤はテールボイド発生のため 沈下する（裏込め注入の操作によってはこれが生じ ないこともあり得る).

(5) トンネル周辺のアーチ作用はほとんどみられな い.

古山 ${ }^{14), 15)}$ ，藤原 ${ }^{11), 12)}$ のデータでも同様の傾向が認め られる（もっとも図一9 のような総合的な判断は示され ていない).したがって，図一9 は沖積粘性土地盤にお ける典型的な地盤変状とみなすことができる.

一方，砂地盤について述べると，地盤の動き自体は粘 性土地盤の場合と変わらないが，図一6，７に示すよう に，地中ではトンネルすぐ上の部分が大きい沈下を示 し，それよりも上方の沈下は小さくなっている. すなお ち土のアーチ作用が発揮され，アーチの内側にゆるみ域

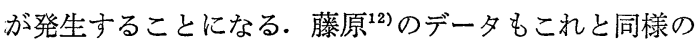
結果を示している. 図一8 はシールド進行方向の水平変 位分布である. シールド切羽部で地盤は前方に押しつけ られているが，影響域は地表まで達していない，以上か ら，この場合の地盤変位は 図一10 に示す模式図のよう になると考えられる.

\section{（2）シールド掘進による地盤の乱れ}

著者 ${ }^{9), 30)}$ は篠崎幹線, 柴又幹線における実態調査に おいて，シールド掘進前後における土性の変化を調査 し, 含水比, 密度, せん断強度, 弾性係数 (これのみボ ーリング孔内載荷試験による) などのチェックを行った が, シールド掘進前後では弾性係数の変化のみが著し く，他はあまり変化がなかった：これと同様のことは桑 原 $^{34)}$, 藤原 ${ }^{12), 13)}$ らも報告している.

図一11に篠崎幹線における地山の弾性係数の変化の 事例を示す. 弾性係数はトンネルの $1 \mathrm{~m}$ 側方で孔内水 平載荷試験を実施して求めたものである. 変化率 $=\left\{\left(E_{2}\right.\right.$ $\left.\left.-E_{1}\right) / E_{1}\right\} \times 100 \%$ で, $E_{1}$ はシールド施工前, $E_{2}$ は施 工後の弾性係数である. 4 本の線は各工区における平均 值を示すものである.

データはばらつきはあるが, 施工後の弾性係数はほと んど減少し, 数点では増加した. 全体を平均すると施工 前の弾性係数の $1 / 2$ 程度となる. なお, 施工が良好な場 合，弾性係数の低下は $1 / 2$ 以下となるので，これを $1 / 2$ とするとおおむね安全側の結果を与える.

（3） シールド掘進に伴う沈下の分類とメカニズム

図一12 は篠崎幹線で計測された沈下 (隆起も含む)の

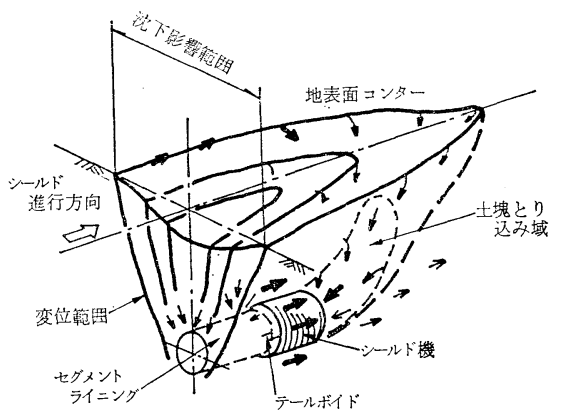

図一9地盤変位模式図（粘性土地盤）

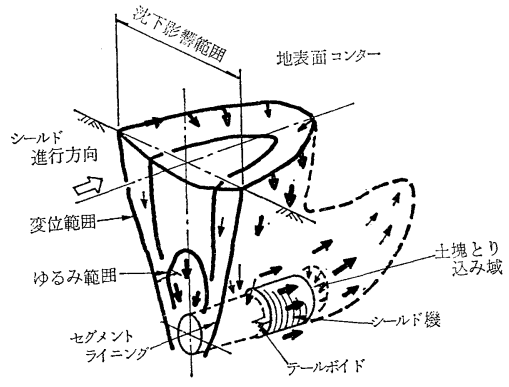

図一10地盤変位模式図（砂地盤）

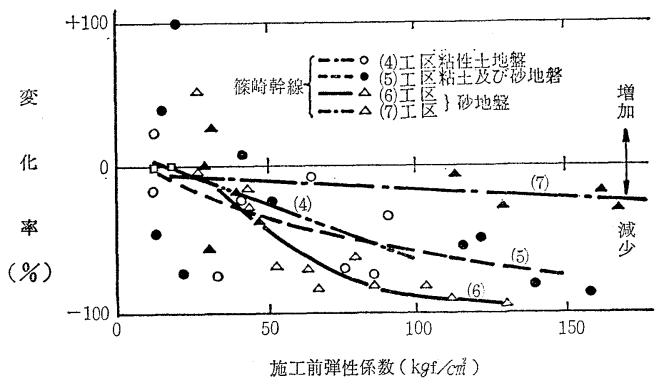

図一11地盤の弾性係数の変化

経時変化の事例である. いずれも地表面の一点のデータ である. 4-2，4-3 地点は粘性土地盤，6-1，6-4 地点は砂 質地盤である. シールド機種は土圧バランス式である.

4-2 地点ではシールド切羽到達以前に沈下が始まって おり, シールド機のテールが通過し，テールボイドが発 生すると急に沈下が増している（裏込め注入は $2 \sim 3$ リ ング遅れでなされた). その後 10 数日間シールドが停止 していた間も沈下が進み, 再び動き出すと一時沈下速度 が増し, 結局ほぼ 100 日経過後沈下は $10 \mathrm{~cm}$ に達して いる.

4-3 地点ではシールド切羽到達前に沈下はほとんどみ られず, 逆に切羽到達からテール通過の間に隆起が生じ ている. 4-2 と 4-3 地点の地盤性状はよく似ており，こ のような挙動の差はシールド切羽を押しつける推力の大 小に起因するものである.

6-1 地点は切羽前面の地盤の崩壊が沈下を生じさせた 事例である.6-4 地点は切羽の崩壊がなく, テールボイ 
ド発生による沈下のみを示した事例である.いずれむ， シールド機通過後，粘性土地盤と比べると，かなり早い 時期に沈下は落着いている.

以上の例からも明らかなように，経時沈下曲線は地盤 の種類，シールド掘進の良否に大きく影響され，この沈 下曲線を分析することによって，沈下に影響する要因を 抽出することができると考えられる.

!著者ら ${ }^{9), 18), 199}$ は地盤の沈下を 図一13 のように 5 段階 に分けて考えた. すなわち，次の (1)〜 (5) である.
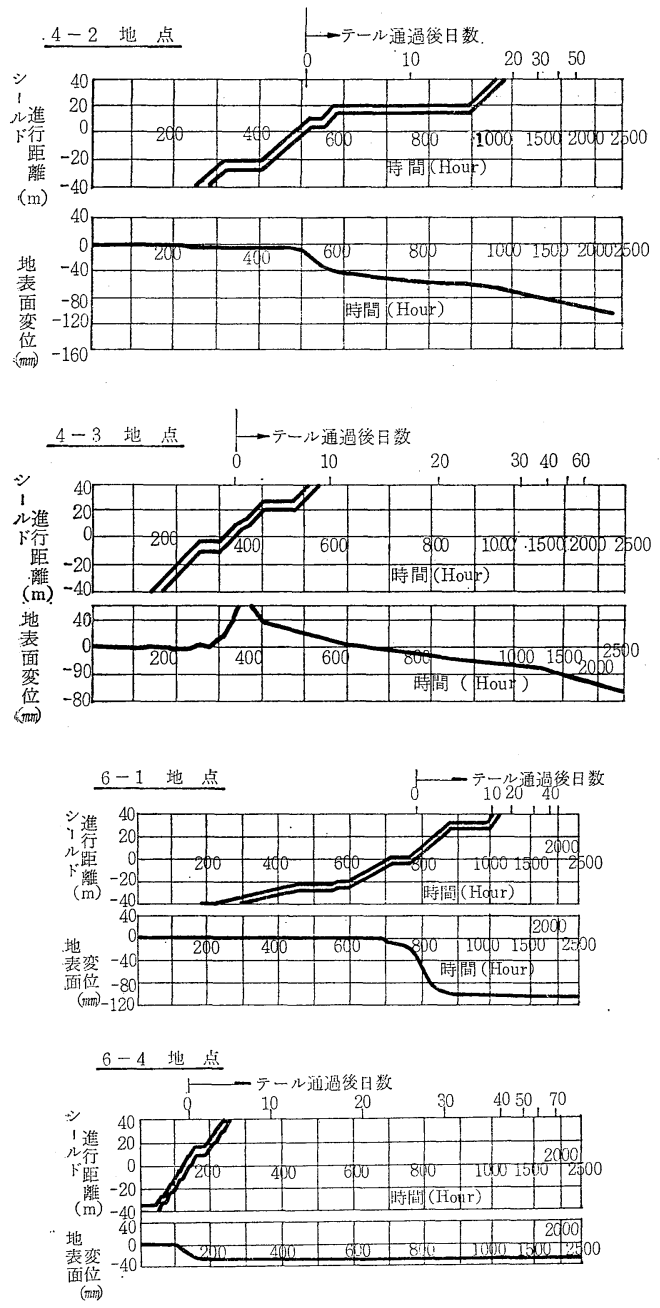

図-12 地表面変位経時変化例（篠崎幹線）

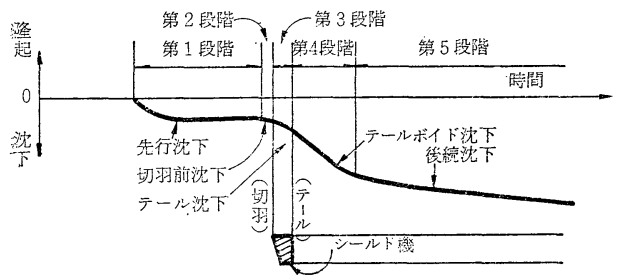

図一13＼cjkstart沈下経時変化曲線模式図
(1) 先行沈下 : トンネル切羽が地表の測定点のかなり 手前（数 $10 \mathrm{~m}$ 程度）にある時期から，切羽が測定 点の直前に至る間に生じるもので，シールド掘進に 伴う地下水位低下によって生じる. したがって，こ れは地盤の有効土被り圧が増加したために生じる圧 縮・圧密沈下である.

(2) 切羽前沈下および隆起 : 切羽が地表の測定点のご く手前（数 $\mathrm{m}$ 程度）に達した時期から，切羽が測定 点直下に達する間に生じる沈下，または隆起現象. 切羽の崩壊, シールドの過推力など, 切羽における 土圧のアンバランスによって生じるもので，地山の 応力解放, 負荷土圧の作用による地盤の弾塑性変形 である・

(3) テール沈下 : 測定点の直下に切羽が 到達してか ら，シールド機のテールが通過するまでの間に生じ る沈下現象. 主として土の乱れに起因する.

(4) テールボイド沈下 : シールド機のテールが測定点 の直下を通過した後に生じる沈下現象. テールボイ ドに起因する地山の応力解放による弾塑性変形であ る.

(5) 後続沈下 : 主として，地盤の乱れに起因する圧密 およびクリープ的残留沈下現象.

表一1 地盤変状のメカニズム

\begin{tabular}{|c|c|c|c|}
\hline 沈下の種類 & 因 & 地盤状況の変化 & 変状メカニズム \\
\hline (1)先行沈下. & 地下水位低下㝵 & $\begin{array}{l}\text { 有効土被り王の } \\
\text { 增加 }\end{array}$ & 圧縮 - 圧密沈下 \\
\hline (2)切羽前沈下 & $\begin{array}{l}\text { 切羽崩壞, 過大な取 } \\
\text { り込区 }\end{array}$ & $\begin{array}{l}\text { 地山の态力解 } \\
\text { 放, 乱れ }\end{array}$ & 弾・塑性変形 \\
\hline 隆起 & 切羽押(込み, & 負荷土圧 & \\
\hline (3)テール沈下 & $\begin{array}{l}\text { シールド機通過時の } \\
\text { 摚乱 }{ }^{9)}\end{array}$ & 乱れ & 压縮 \\
\hline $\begin{array}{l}\text { (4)テールボイ } \\
\text { ド沈下 }\end{array}$ & テールボイドの発生 & 地山の応力解放 & 弹・塑性変形 \\
\hline (5)後 続 沈下 & 以上全要因(残留分) & & 压縮および尗 \\
\hline
\end{tabular}

表一2 地盤変状原因と影響要因

\begin{tabular}{|c|c|c|c|c|}
\hline 因 & 補助工法 & シールド機 & 裏込め注入 & 施工管理 \\
\hline 垰下水位低 & $\begin{array}{l}\text { - 地下水位低 } \\
\text { ·法 } \\
\left.\text { ·圧気工法 }{ }^{9}\right) \\
\text { ·不完全な薬 } \\
\text { 液注入工法 }\end{array}$ & 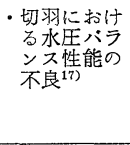 & 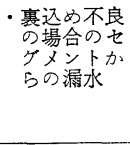 & 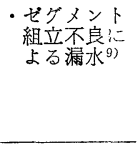 \\
\hline $\begin{array}{l}\text { 切羽の崩壤 } \\
\text { 切羽の押込 } \\
\text { 幺 }\end{array}$ & ・不完全な䇶 & 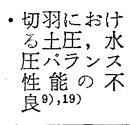 & & 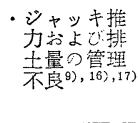 \\
\hline $\begin{array}{l}\text { テールポイ } \\
\text { ドの発生 }\end{array}$ & & 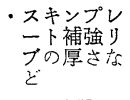 & $\begin{array}{l}\text { ・注入量の不 } \\
\text { 足) (注入 } \\
\text { 時期の遲れ } \\
\text { による) }\end{array}$ & 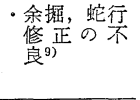 \\
\hline 地盤の乱れ & 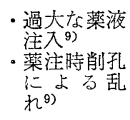 & 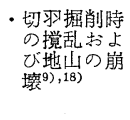 & & $\begin{array}{l}\text { - 過推力, 過 } \\
\text { 少推力江 } \\
\text { る地山の過 } \\
\text { 度の率状9 }\end{array}$ \\
\hline
\end{tabular}


これらの沈下は常にそのすべてが生じるものではな く，地盤状況，施工条件によって卓越する沈下の種類が 異なる.

著者らのこれまでの経験から，地盤変状は 表一1 に示 す原因とメカニズムで生じ，沈下の原因は 表一2 に示す ような補助工法，シールド機，裹込め注入，施工管理の 要因と関連することがわかってきた.

以上のことから，地盤変状予測においては 表一1，2 に示す事項を解析計算中に定量的に組み込むことができ なければならない。

\section{3. 地盤変状解析}

\section{（1）変状解析の取り組み方}

前節で述べたように，シールド掘進に伴う地盤の沈下 は (1) (5)の 5 段階に分けられる.それぞれが異なった 原因が重なって生じるものであるから，1つの手法で変 状の予測解析を行うことは不可能であるといえる. そこ で, 著者らは地盤変状を次の 3 つに分解して算定するべ きであると考えている.

A）圧縮・圧密沈下 : 地下水位の変化を予測し, 通常 の圧密沈下計算手法により (1) の計算を行う.

B）応力変化による地盤の変形：弹性解析（あるいは 弹塑性解析) により (2), (3), (4) の計算を行う.

C) クリープ沈下 : 粘弾性解析または実測值による統 計処理の結果を参考にして (5) の計算を行う.

A)，C) については本論文では省略し，B）について 行ったいくつかの検討結果を報告する.

これについての解析手法は沈下だけでなく，隆起をも 対杽としなければならない，また，地盤の土層構成，シ ールド機の機能，裹込め注入状況，施工管理状況などの 要因を解析に組み込むことができねばならない。このよ うな条件をことごとく考慮できる解析法は現在のとこ ろ，有限要素法以外に見当たらない。

有限要素法には二次元と三次元のものがある. 実際の 地盤変状は前述のとおり三次元的に生じるので, 解析も 三次元有限要素法を用いるのが理想であるが，大力デー タが膨大な量となり，簡単なケースを除けば実用上困難 である.そこで，以下に迹べるような倹討を行って二次 元解析を適用してみたが, 観測結果をかなり説明するこ とができた。

\section{(2) 横断方向解析}

横断方向解析は地盤沈下と地盤隆起の場合で解析モデ ルの設定の仕方が異なる.

まず地盤沈下解析の場合について述べる．この場合の
解析を行らにあたってまず留意しなければならないこと は，テールボイド量とセグメントライニングの剛性が考 慮されなければならないことである.このようなことを 考慮しない素掘り型のモデルでは，ともすると，シール 周辺地盤がセグメントの位置をはるかに越えた変位を与 えるといら実状に合わない結果を与える. 著者ら ${ }^{24)}$ は地 山掘削面とセグメントライニングの閒に，有限のテール ボイド量を大力できるようなプログラムを作成した，そ の結果，テールボイドの大きさ，セグメントの剛性を組 み入れるだけでなく，実際の施工手順に伴う地盤状況の 変化を解析に考慮できるようになった. 解析プログラム のフローチャート，テールボイドとセグメント剛性を組 み込むための手順は 図一14 のと打りである.

まず，素掘り状態の地山の変位を算定し (2)，この值 がテールボイド量より大きい場合は地山の変位量をテー ルボイド量に限定した場合のセグメントライニングによ る反力を求め (3)，これを節点力としてセグメントライ ニングに作用させてセグメントライニングの変位量を求 め (4), 最終の変位置を算出するものである. この解析 モデルによって，裹込め注入の良否はテールボイド量の 大小として，また切羽崩壊の影響もセグメント周团の余 掘量として解析に組み込むことが可能となる. シールド 掘進に伴う地盤の乱れの影響は，あるゆるみ範囲の地盤 の弾性係数を変化させることによって反映させることが
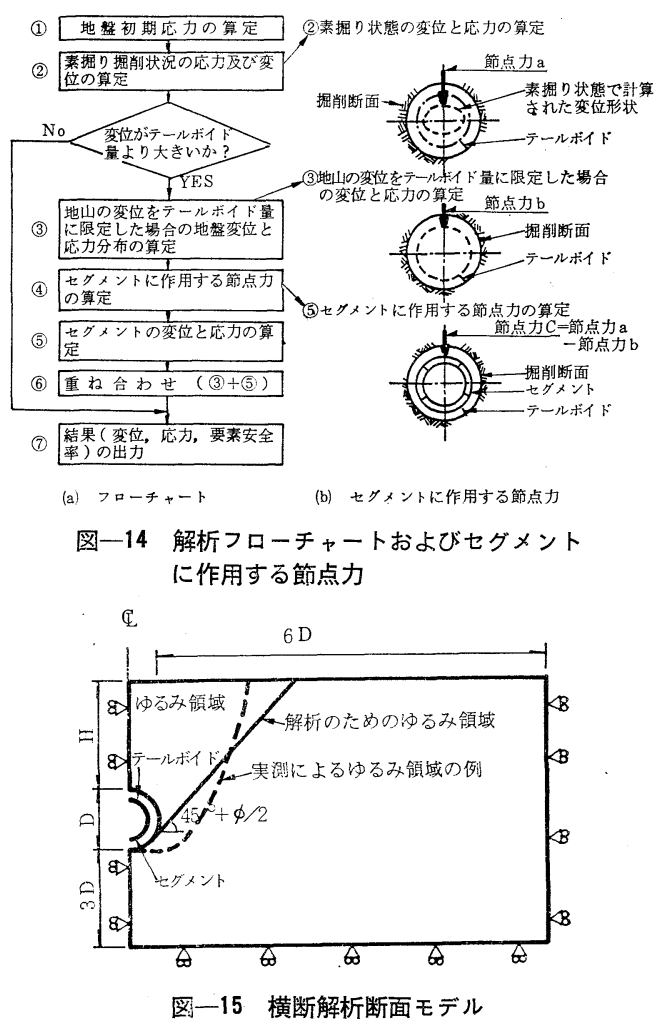
できる. 標準的な解析断面を 図一15 に示す. 最終状態 の沈下計算を行う場 合には，ゆるみ範囲を $45^{\circ}+\phi / 2$ ( $\phi$ : 内部摩擦角) の傾きの直線とすると, 図中の実測ゆ るみ範囲に基づく計算と大差ない結果を得た ${ }^{33)}$ ．また, モデルの寸法は幅をシールド径 $(D)$ の 6 倍, 深さを 3 倍程度にとれば十分である.

次に土質定数の決め方について述べる. 図一9，10 に 示すように, シールド掘進に伴う地盤沈下はシールド機 を中心とする舟底形に地中分布しており，それがシール ド機の進行とともに前進し広がってゆく.そしてその 際，図一11 に示すように地山の弾性係数が著しく低下 することが確認されている. この変化は模式的に図一16 のように表わせる.

A 地点が解析断面である.この位置からみると地表面 沈下は，シールド機が十分離れた位置 1 から， 2, 3 と接 近し通過する間に（a）図に示すようにゼロ， $S_{2}, S_{3}$ と 増え，ゆるみ範囲は（c）図のようにゼ口， $\alpha_{2}, \alpha_{3}$ と広 がる. そして地盤の弾性係数は自然状態の值 $E_{1}$ から, 乱されて $E_{2}, E_{3}$ へと低下する. したがって, 有限要素 法によってシールド掘進後の最終沈下量を算定する場 合，ゆるみ範囲 $\alpha_{3}$ とその部分の弾性係数 $E_{3}$ を入力す ればよい: $\alpha_{3}=45^{\circ}+\phi / 2, E_{3}$ を図一11 に示す実績を参 考にして $E_{1}$ の $1 / 2$ とすれば，これまでの経験では十分 な精度の結果を得ている.

図一17 は上記の手法で解析した一事例で，沈下，水 平変位ともに計算值と実測值がよく一致している. 入力 した土質定数は図中に示してある. 地盤の弾性係数 $E_{1}$ は現位置において孔内水平載荷試験を行って求めたもの である.

このほかにも，同じ解析手法を適用した例は多いが, 沖積地盤で土被り厚さがシールド径の 2.5 倍以下であれ ばほとんどよい一致をみた。

次に地盤隆起解析について述べる. 地盤隆起はシール

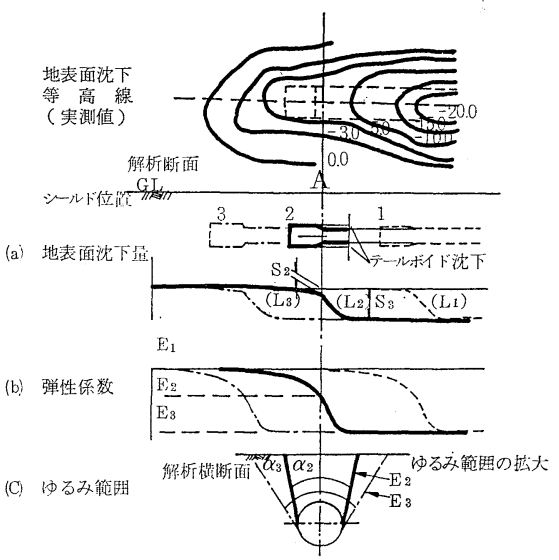

図一16 弾性係数之ゆるみ範囲の推移

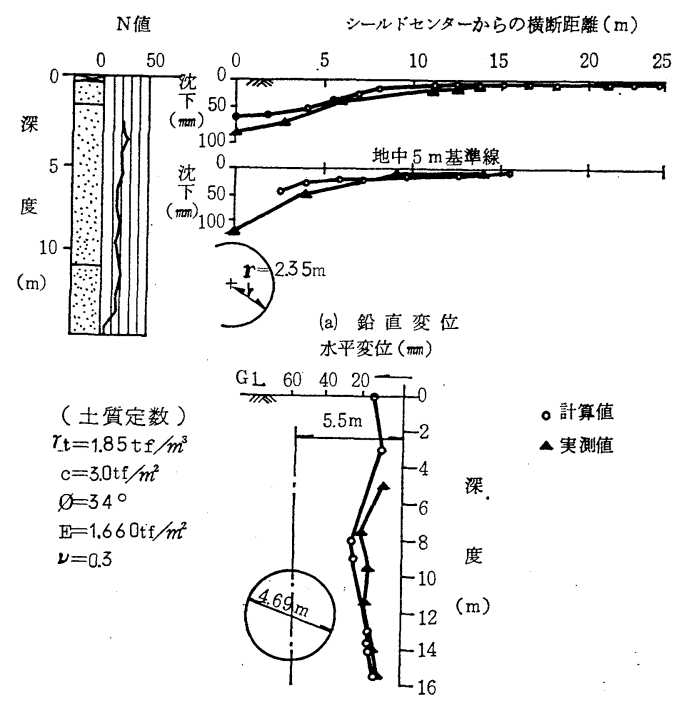

(b) 木平変位

図一17計算値と実測值の比較（篠崎幹線 6-1）

ド推進時の過推力がシールド切羽における負荷土圧, シ ールド機の周辺摩擦力となって, 周辺地山を受衝土圧的 に押しつけることによって生じるものである.したがっ て, 力の作用する方向が異なるために, 二次元横断解析 では，そのまま切羽の負荷土圧，シールド機の周辺摩擦 力を入力することができない．解析モデルとしては図一 18 に示すように, 過推力によって生じる地山の負荷土 圧の横断方向成分を仮想応力として地山掘削面に作用さ せることが考えられる.この場合でも，ゆるみ範囲の土 の弹性係数は前述の沈下解析の場合と同様に低減させ る.

この解析では, 作用させる仮想応力は当然施工の方法 によって異なり，経験的に推定するほかない，そこで， 施工実績から仮想応力を逆算することを試みた.

梅田幹線 ${ }^{31)}$ (シールド外径 $7.0 \mathrm{~m}$, 土被り $7.5 \mathrm{~m}$ ), 青 井幹線 ${ }^{31)}$ (シールド外径 $5.18 \mathrm{~m}$ ，土被り $8.3 \mathrm{~m}$ ) シー ルドトンネルは沖積粘土地盤に対し，ブラインドシール ドによって施工された。この現場 では 図一19 (a), (b) に示すような地表面隆起が測定された. この場合の負荷 土圧を逆算する手順は, それぞれの場合について仮想応 力を 3 通り変化させて, 地表面隆起分布ならびに地表面 最大隆起量を仮想外力との関係を求めておき, この計算 結果と現場実測值を比較するのである.

この解析では地盤が粘土であるために ので，ゆるみ範囲を $45^{\circ}$ の傾斜とし, その中の地盤の弾 性係数はシールド掘進前の $1 / 2$ とした. なお, 梅田幹線 の場合は，下部に並行して通っている既設管もシールド 工法で施工しているので, 上記の操作を 2 度繰り返し た. 1 


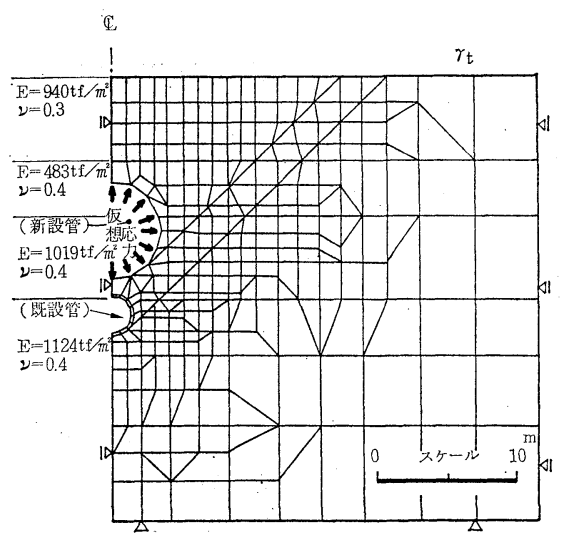

図一18地盤隆起解析モデル例（梅田幹線）
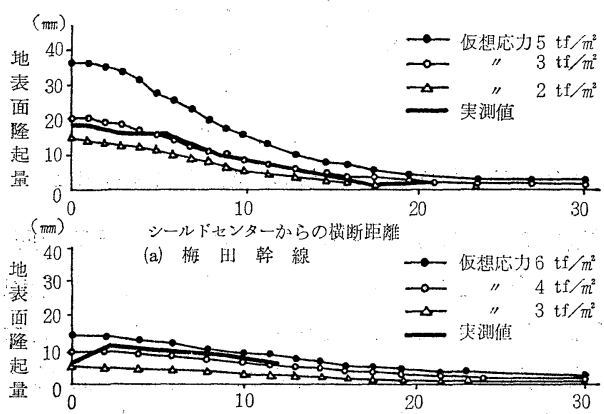

シールドセンターからの㨏断距離

(b). 青并幹線

図一19 地表面隆起解析結果

\begin{tabular}{c|c|c|c}
\hline 仮 想 底 $力$ & 2 & 3 & 5 \\
\hline $\begin{array}{c}\left(\mathrm{tf} / \mathrm{m}^{2}\right) \\
\text { 地表面 最大 }\end{array}$ & 14.7 & 20.8 & 36.9 \\
\hline
\end{tabular}

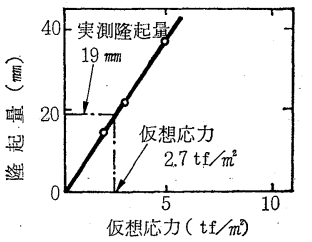

(a) 梅田幹線
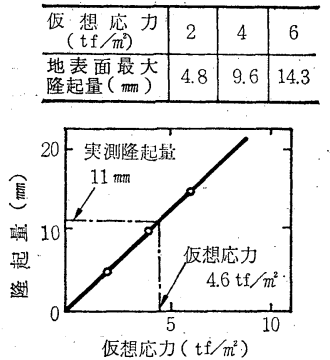

(b) 青井幹線
図一20 地表面隆起解析検討結果

解析の結果から得られた地表面隆起の横断分布を実測 值とともに 図一19 に示す. 両ケースとも計算值と実測 值の分布形状はよく似ており，地盤が押し上げ力により ほぼ弾性的に挙動していることを示している. なお，青 井幹線の実測值がトンネル中央でやや隆起が小さくなっ ている ((b) 図) のは, 図一19（a）に示す梅田幹線の 場合と逆に新設シールドの上方 $1 \mathrm{~m}$ に直径 $3.25 \mathrm{~m}$ の既 設管があり，それらが互いに浅い角度で交差するような 平面配置となっていたために, その縦断方向の剛性で地 盤隆起が抑制されたものである. 計算は二次元なのでこ の点は考慮に入れていない。

次に, シールド中心線上に抒ける隆起量と仮想外力の
表一3 仮想応力とジャッキ推力

\begin{tabular}{|c|c|c|c|c|c|}
\hline & $\begin{array}{l}\text { 地表面 } \\
\text { 隆 起量 } \\
(\mathrm{mm})\end{array}$ & 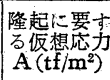 & 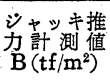 & $\begin{array}{l}\mathrm{A} / \mathrm{B} \\
(\%)\end{array}$ & その 他 \\
\hline 梅田幹線 & 19 & 2.7 & 43 & 6.3 & 粘士地盤 \\
\hline 青井 & 11 & 4.6 & 56 & 8.2 & 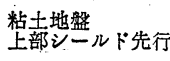 \\
\hline
\end{tabular}

関係から，実際の押し上げ力を推定する手順は図一20 (a)，(b) に示すとおりである. 推定される押し上げ力 は梅田幹線で $2.7 \mathrm{tf} / \mathrm{m}^{2}$, 青井幹線で $4.6 \mathrm{tf} / \mathrm{m}^{2}$ で, こ れらは表一3 に示すようにジャッキ推力の $6 \sim 8 \%$ 程度 である.

以上の推論は地盤の実際の挙動を一応合理的に説明で きる点で，大きな誤りはないと考えている. なお，この ような隆起の予測は，次節に説明する縦断方向解析が先 行すべきことは当然である.

\section{（3） 縦断方向解析}

シールド工事において縦断方向解析が必要となるの は，掘削土の取り込み量, 泥水圧, 泥土圧, ジャッキ推 力などの管理が不適切で, シールド切羽における土圧の バランスが崩れ，近接構造物に負荷土圧や強制変位が起 こるおそれのある場合である.

シールド掘進時の縱断方向の地盤変状は明らかに三次 元的な挙動であるために，縦断方向解析は横断方向解析 のように簡単に二次元平面ひずみ問題として取り扱うこ とはできない. そこで图一21 に示す単純な矩形要素モ デルによって, 二次元, 三次元有限要素法弾性解析の比
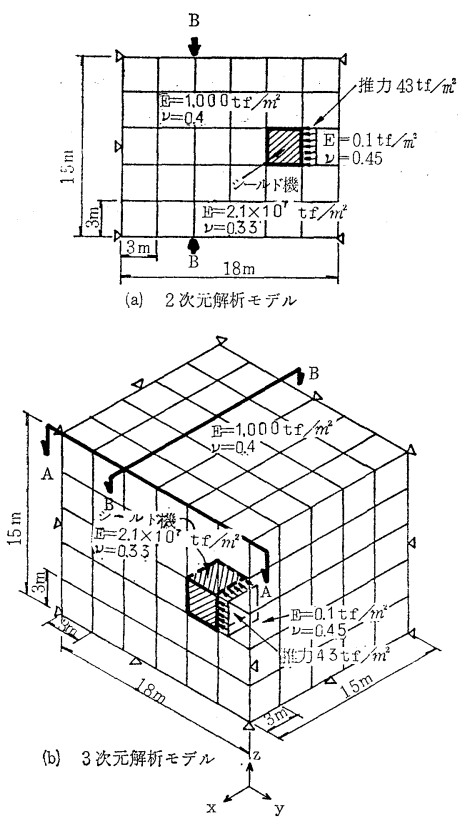

図一21比較計算のための解析モデル 
切羽前方距離 $(\mathrm{m})$ 切羽前方距離 $(\mathrm{m})$

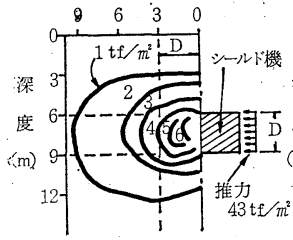

(a) 3 次元解析 (A-A 断面)

図一22 シールド位置と水平土圧分布

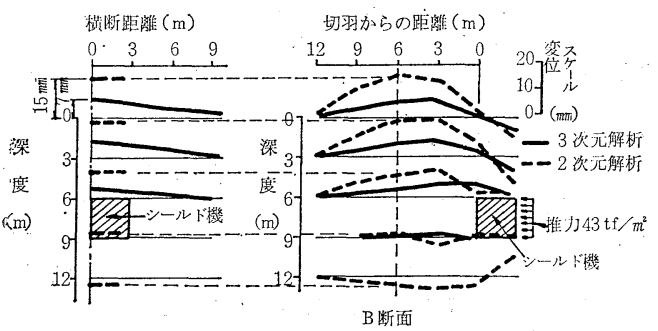

(a) 㮐断 ( B 断面)

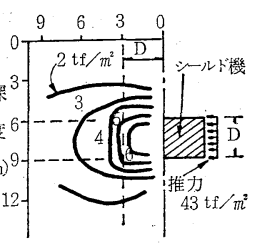

(b) 2 次元解析

\section{図一23 鉛直変位分布図}

較を行った. このモデルは梅田幹線の事例を模式化した ものである.

図一22, 23 は計算結果の水平土圧分布, 鉛直土圧分 布である. 水平土圧はシールド切羽から前方に遠ざかる ほど分散, 減少するが，その度合は当然三次元解析の方 が大きく, 切羽前方 $1 D$ の範囲では二次元の場合に比し 約 70\% の土圧強度となっている. 地盤の鉛直変位はピ 一ク值に注目すると, 二次元解析の場合が三次元解析よ りも約 2 倍大きな值を示している.

以上の結果から, 綎断方向解析は複雑な三次元解析に よらなくても，上の例のような両者の差に留意しさえす 水ば，簡単な二次元解析によってある程度有用な情報が 得られると考えられる。

次に示す事例は，3.(2) でも述べた梅田幹線を既設シ 一ルドトンネル（外径 $3.26 \mathrm{~m}$, 手掘式）の $1 \mathrm{~m}$ 直上を ブラインドシールドで掘進施工したときの縱断方向解析 である. ごく近接して存在する既設管に与える, シール ド掘進時の負荷土圧の影響を検討したものであるが，今 洄は地表面の変状についてのみ報告する.

解析断面モデルを図一24 に示す.モデルの境界条件， 解析定数は（a）図，荷重載荷条件は（b)，(c) 図に示す とおりである. なお，入力定数のうちシールド機テール 以後のシールド上方地盤の弾性係数と既設シールドトン ネルの弾性係数を次のように定めた. 前者はシールド掘 進に伴う地盤のゆるみ域であるから，篠崎幹線実態調査 結果より，自然状態の地盤の弾性保数の $1 / 2$ に設定し た. 後者はたわみ性管路を二次元平面要素で扱えるよ

う, 実際の既設トンネルのたわみ性とトンネル平面要素 䉼面のたわみ性が等価となるような弾性係数を設定し

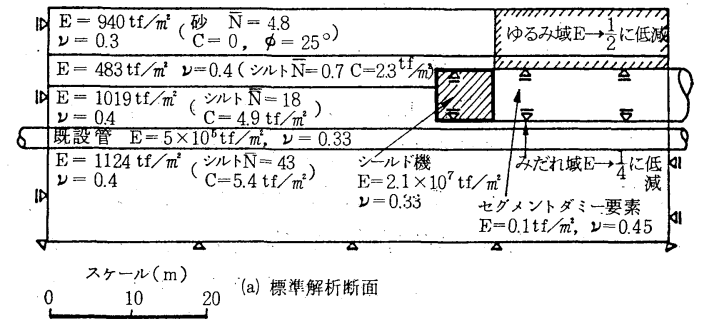

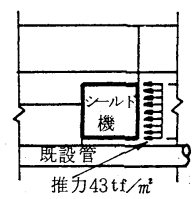

（b）推力の載荷（ケースI)

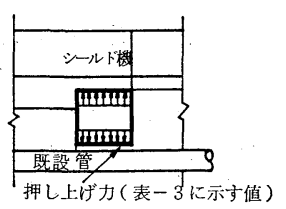

(C) 押し上げ力の载荷 (ケースII)
図一24 梅田幹線綐断解析モデル
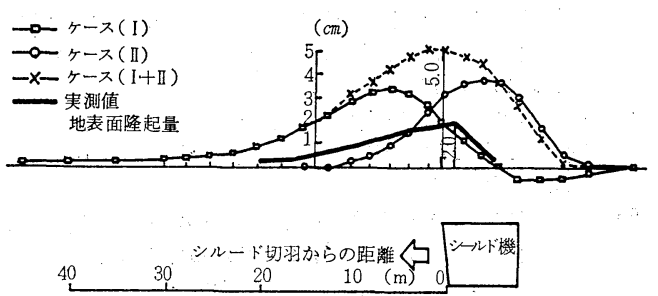

図一25 地表面変位解析結果

た.

解析結果を 図一25 に示す.この二次元解析で得られ た地表面変位は 図一24の (b), (c) 等のモデル単独で は変位量, 分布形状とも害測值をうまくシミュレーショ ンすることができず，図一25 に示すように（b) と (c) を重ね合わせることによって，地表面の分布形状を実測 值と合わせることができた. 計算值の最大隆起量は実測 值の 2.5 倍であり，これは前記の比較計算から 推定し て, 三次元問題を二次元モデルで扱ったための差と解釈 される.

切羽前面の水平負荷土圧，㧤よび既設管に作用する鉛 直方向負荷土圧分布などの結果は省くが，(b) の荷重条 件がおおむね実測值に近い計算値を与えた。

\section{4.あとがき}

著者らは過去 7 8 年の間に 20 数例の現場計測を行 い，その間に試行錯誤を繰り返しながら，今回報告した 解析法に到達することができた. 最近は入念な動態計測 管理が普及し，ほとんど地盤変状を生じさせなかった施 工例 ${ }^{32}$ すら報告されていることはまことに喜ばしい。

しかし，地質，シールド機，近接構造物からの要求の 組合せはさまざまであり，地盤変状の予測の必要性は今 後とも否定されることはないだろう. 本論文で著者らが 提案した手法が，このような問題解決の一助ともなれば 
幸いである.

最後に, 本論文で扱った篠崎幹線, 梅田幹線, 青井幹 線のシールド工事に関し，東京都下水道局および多数の 建設会社の関係各位には長年にわたり現場計測のご支援 をしていただいた．また，日本工営（株）の杉山仁実， 田中 弘の両君には数值計算にご協力いただいた. なお 大阪市立大学の三笠正人教授には本論文とりまとめに際 し，多くのご助言・ご指導をたまわった. あわせて，こ こに感謝の意を表する次第である.

\section{参 考 文 献}

1）今中利信・中村重政：大断面シールドにおける重要構造 物防護について, 土木学会第 35 回年次学術講演会講演概 要集, 第 3 部, pp. 480 481, 昭和 55 年.

2）中村重政ほか：シールド工事施工における重要構造物防 護計画と施工結果, 土木学会第 36 回年次学術講演会講演 概要集, 第 3 部, pp. 368 369, 昭和 56 年.

3）志村益世ほか：腐植土層におけるシールド掘進に伴う地 表面沈下について, 第 15 回土質工学研究発表会概要集, pp. 1545 1548, 昭和 55 年.

4）小管英嗣ほか：盛土に近接したシールド工事における地 盤挙動, 第 17 回土質工学研究発表会概要集, pp. 1225 1228, 昭和 57 年.

5）松崎茂樹 : 重要構造物の直近を シールドで貫く，トンネ ルと地下, 第 16 巻 6 号, pp. $45 \sim 51,1985$.

6）峯尾正臣：軟弱地盤における地盤沈下の試験工事, トン ネルと地下，第 14 巻 4 号, pp. 31 40, 1983.

7）橋本定雄 : 上下隣設シールドの施工と追跡調查 (2), トン ネルと地下, 第 13 巻 7 号, pp. 43〜54, 1982.

8）橋本定雄：上下隣設シールドの施工と追跡調査 (1),トン ネルと地下, 第 13 巻 5 号, pp. 7〜14, 1982.

9）東京都下水道局：篠崎幹線シールド工事実態調査に伴う 解析, 昭和 54 年.

10）森 麟・赤木寛一：軟弱粘土地盤でのシールド工事に 伴ら地盤沈下状況の特徴とその要因, 土木学会第 35 回年 次学術講演会, 第 6 部, pp. $476 \sim 477$, 昭和 55 年.

11）藤原正明ほか：土圧シールド工事における現場計測結果, 第 16 回土質工学研究発表会概要集, pp. 1529 1532, 昭 和 56 年.

12）藤原正明・尾儀一郎：シールド周辺地山の実応力, ひず みの検討, 土木学会第 36 回年次学術講演概要集, 第 3 部, pp. 370 371, 昭和 56 年.

13）藤原正明ほか：土圧シールド工事における現場計測結果, 第 17 回土質工学研究発表会概要集, pp. 1237 1241, 昭 和 57 年.

14）古山政勝ほか：シールド工事における 地盤変状測定，第 15 回土質工学研究発表会概要集, pp. 1549 1552, 昭和 55 年.

15）古山政勝ほか：シールド工事における地盤変状測定（そ の 2), 第 16 回土質工学研究発表会概要集, pp. 1537〜 1540 , 昭和 56 年.

16）森 麟ほか：シールド推進時におけるる切羽地盤の動き
と取り込み土量との関係, 土木学会第 40 回年次学術講演 会講演概要集, pp. 335 337, 昭和 60 年。

17）小林健郎・西松裕一：シールド掘進に伴ら地盤変位に関 する研究, 土木学会論文報告集, 第 328 号, pp. $77 \sim 88$, 1982.

18）山田孝治ほか：シールド掘削に伴う地盤沈下測定結果, 第 15 回土質工学研究発表会概要集, pp. 1541 1544, 昭 和 55 年.

19）間片博之：下水道シールド工事における地盤沈下対策（1 ４), 下水道協会誌, Vol. 17, No. 191 195, 1980.

20) Peck, R.B. : Deap Excavations and Tunneling in Soft Ground, State-of-the art reports, 7th ICOSMFE (Mexico), pp. 225 290, 1969.

21）たとえば，K. チェッキー：「トンネルエ学」(島田隆夫 訳), 鹿島出版会.

22）伊藤冨雄ほか：シールド掘削による 地表面沈下の三次元 解析, 第 16 回土質工学 研究発表会 概要集, pp. 1569 1572, 昭和 56 年.

23） 久武勝保・伊藤富雄 : トンネル掘削によって生じる地表 面沈下の境界要素法による 三次元解析, 土木学会論文報 告集, 第 327 号, pp. 155 162, 1982.

24） 久武勝保・竹山 喬・伊藤富雄 : 既設シールドトンネル による地表面沈下の算定手法とその現場への適用, 土木 学会論文報告集, 第 332 号, pp. 75 83, 1983.

25）山田孝治ほか：有限要素法によるシールド掘進に伴う地: 盤沈下解析, 第 14 回土質工学研究発表会概要集, pp. $817 \sim 820$, 昭和 54 年.

26）寺田正治・苗村康造：シールド掘進に伴う沈下の要因に ついて, 第 16 回土質工学研究発表会概要集, pp. 1533 1536, 昭和 56 年.

27）木村洋行ほか：切羽の進行を考慮した掘削の解析につい $\tau$, 第 16 回土質工学研究発表会概要集, pp. 1565 1568, 昭和 56 年.

28) Ghaboussi, J. et al. : Finite Element Simulation of Tunneling over Subway, Journal of Geotechnicali Engineering, Vol. log. No. 3, ASCE, 1983.

29）大田秀樹ほか：シールド掘進を考慮した FEM 解析, 第 20 回土質工学研究発表会概要集, pp. 1525 1528, 昭和 60 年.

30）東京都下水道局 : 柴又, 東南幹線シールド工事実態調査 報告書, 昭和 56 年.

31）東京都下水道局：上下複線シールド工事実態調查に伴う 解析, 昭和 58 年.

32）平田武弘：土圧式シールド掘削に伴う軟弱粘性土地盤の 挙動と施工管理, 土木学会論文集, No. 355, pp. 114 123, 1985.

33）山田孝治ほか : 有限要素法によるシールド掘進に 伴 う地 盤沈下解析 (その 2 ), 第 15 回土質工学研究発表会, pp 1553 1556, 昭和 55 年.

36）桑原 力・小林健郎・青山菊男 : シールド現場で行った 計測例，トンネルと地下，第 13 巻 1 号, pp. 27〜34, 1982 .

(1986.4.23.受付)

\section{ご案内○}

『土木学会論文集・第VI部門』は年 2 回 ( 3 月，9月）の発行です. 別揭の投稿要項等をご臨のうえ，多数の論: 文をお寄せ下さい。

なお，不詳点等は事務局編集課（電話 03-355-3441 番，内線 153）あてお願いします。 